\title{
Nutraceutical with Anti-Inflammatory Activity for the Management of Airway Remodeling in Bronchial Asthma: Kalanchoe integra Var. Crenata (Andr.) Cuf Leaf Extract
}

\author{
Asiedu-Gyekye Isaac Julius ${ }^{*}$, Awortwe Charles ${ }^{2}$, Nyamekye Effah Samuel1, \\ Antwi Daniel Ansong³, Seidu Mahmood4, Adjei Samuel5, Banga N'guessan Benoit Kwame1, \\ Amoateng Patrick ${ }^{1}$, Nkansah Edwin ${ }^{1}$ \\ ${ }^{1}$ Department of Pharmacology and Toxicology, University of Ghana School of Pharmacy, College of \\ Health Sciences, Legon, Ghana \\ ${ }^{2}$ Division of Pharmacology, Faculty of Health Sciences, University of Stellenbosch, Cape Town, South Africa \\ ${ }^{3}$ Department of Physiology, University of Ghana Medical School, College of Health Sciences, Korle-Bu, Ghana \\ ${ }^{4}$ Department of Chemical Pathology, School of Allied Health Sciences, College of Health Sciences, \\ Korle-Bu, Ghana \\ ${ }^{5}$ Department of Animal Experimentation, Noguchi Memorial Institute for Medical Research, College of \\ Health Sciences, Legon, Ghana \\ Email: asiedugyekye@yahoo.co.uk, ijagyekye@ug.edu.gh, Charzos@yahoo.com, danantwi@gmail.com, \\ sadjei@noguchi.mimcom.org
}

Received 9 December 2013; revised 13 February 2014; accepted 5 March 2014

Copyright ( 2014 by authors and Scientific Research Publishing Inc.

This work is licensed under the Creative Commons Attribution International License (CC BY).

http://creativecommons.org/licenses/by/4.0/

(c) (i) Open Access

\section{Abstract}

Background: Kalanchoe integra is widely used in folklore medicine as an antiasthmatic agent. Previous studies have shown the ameliorating effect of Kalanchoe integra leaf extract [KILE] on bronchial hyperesponsiveness and inflammation. Further, the stabilizing effect of Kalanchoe sp on mast cell degranulation, suggests that Kalanchoe species are suitable candidates for allergic asthma therapy. This study is designed to investigate the anti-asthmatic potential of KILE and monitor the accompanying histopathological and immunobiochemical changes that occur in an animal model of bronchial asthma using ovalbumin sensitized guinea pigs. Method: Thirty male guinea pigs were divided into five groups of six animals each. Bronchial asthma was simulated in guinea pigs using ovalbumin. Both low dose $(300 \mathrm{mg} / \mathrm{kg})$ and high dose extract $(900 \mathrm{mg} / \mathrm{kg})$ were administered daily for 42 days. Prednisolone $(2.5 \mathrm{mg} / \mathrm{kg})$ was the standard drug used. Results: Guinea pigs in all KILE treated groups maintained the integrity of their airway structures: bron-

\footnotetext{
${ }^{*}$ Corresponding author.
}

How to cite this paper: Julius, A.-G.I., et al. (2014) Nutraceutical with Anti-Inflammatory Activity for the Management of Airway Remodeling in Bronchial Asthma: Kalanchoe integra Var. Crenata (Andr.) Cuf Leaf Extract. Pharmacology \& Pharmacy, 5, 250-261. http://dx.doi.org/10.4236/pp.2014.53032 
chial folds and walls, alveoli, alveolar ducts and sacs. KILE and prednisolone caused a reduction in immune parameters $(p<\mathbf{0 . 0 0 1})$, extent of bronchoconstriction, bronchial wall thickness and goblet cell accumulation in the sensitized guinea pigs. Conclusion: This study demonstrates the anti-asthmatic potential of KILE during prolonged administration by the oral route.

\section{Keywords}

\section{Kalanchoe Integra; Asthma; Bronchoconstriction; Goblet Cells; Perivascular Oedema}

\section{Introduction}

Plant-derived medicines in recent time have immensely contributed to the management of disease conditions in humans [1]. Kalanchoe integra (syn. Kalanchoe spanthulata, Bryophyllum pinnata) [2] [3] is emerging plant of interest of multipurpose use. Boiled leaf extracts are useful in the management of acute and chronic bronchitis, pneumonia, bronchial asthma and palpitation [4]-[6]. This plant has also shown various pharmacological activities such as anthelmentic, immunosuppressive, wound healing, hepatoprotective, antinociceptive, anti-inflammatory, antidiabetic, nephroprotective, antioxidant, antimicrobial, analgesic, anticonvulsant, and antipyretic activity. In South-Eastern Nigeria, this herb is used to facilitate the dropping of the placenta of new-born babies [7]-[11].

Bronchial asthma is a multi-factorial disease process with both genetic and allergic origin characterized by bronchial airway inflammation, increased mucous production and airway hyperresponsiveness [12]-[14]. The prevalence of asthma, along with asthma-associated morbidity and mortality, continues to increase worldwide, making the disease an important target for the biopharmaceutical industry. The development of new therapeutics therefore depends on suitable pre-clinical models; the goal of which is to reproduce airway inflammation, mucus hypersecretion or airway hyper-responsiveness as occurs in humans [15]-[17]. Agents targeting the mechanisms involved in eosinophil and neutrophil activation and accumulation also serve as important therapeutic strategies [15]-[20].

Leaf of Kalanchoe integra contains flavonoids (quercetin) and tannins which have been found to have beneficial effects in the management of bronchial asthma [21]-[24] while the anti-histaminic and anti-anaphylactic effects of Kalanchoe sp have also been demonstrated by researchers [9] [25]. Previous studies have shown the ameliorating effect of Kalanchoe integra leaf extract on bronchial hyperesponsiveness and inflammation [26]. Further, the stabilizing effect of Kalanchoe sp on mast cell degranulation, suggests that Kalanchoe sp could be potential candidates for allergic asthma therapy. It is against this background that this study is being conducted in an attempt to demonstrate the anti-asthmatic potential of Kalanchoe integra leaf extract [KILE].

\section{Materials and Methods}

\subsection{Collection and Identification of Plant Material}

Fresh leaves of Kalanchoe integra were obtained from the Botanical Gardens of the University of Ghana. The collection was done mid-July because the leaves are known to possess high concentrations of its medicinal actives during this season. The leaves were sent to the Botany Department of the University of Ghana for identification, authentication and storage at the herbarium, botany department, University of Ghana Legon for reference purposes. A sample was deposited with identification number IAGSP-001. The fresh leaves were washed thoroughly under running tap water and air dried under the shade for three weeks and pulverized into coarse powder.

\subsection{Preparation of Plant Extract}

$3 \mathrm{~kg}$ of dried Kalanchoe integra leaves were washed and blended, macerated using 12 litres of hot distilled water, decanted and sieved. The concentrated extract was freeze dried. Powdered sample of the plant extract was weighed, labeled and stored in sterile bottles. Two hundred grams (200 g) of the coarse powder was put into a beaker and macerated with four litres of distilled water for 48 hours. The supernatant was filtered using a funnel 
plugged with cotton wool. The filtrate was concentrated under vacuum in a rotary evaporator at $50^{\circ} \mathrm{C}-60^{\circ} \mathrm{C}$. The concentrate was stored in an airtight container at $6^{\circ} \mathrm{C} \pm 2^{\circ} \mathrm{C}$. This concentrate was then freeze dried. The freeze dried extract was $426 \mathrm{~g}$ with a percentage yield of $14.2 \%$.

\subsection{Animal Husbandry}

Thirty (30) guinea pigs of both sexes weighing between 400 and 600 g were purchased from the Noguchi Memorial Institute for Medical Research, University of Ghana. The animals were quarantined in an air-conditioned room for 7 days at a temperature of $22^{\circ} \mathrm{C} \pm 1{ }^{\circ} \mathrm{C}$ with relative humidity of $60 \% \pm 1 \%$ and $12 \mathrm{~h}$ light/dark cycle at animal experimentation department of NMIMR. They were fed with autoclaved Sankofa goat and sheep pellet diet from Ghana Agro Food Company (GAFCO) and water ad libitum every morning throughout the study.

Spontaneous behaviors of all guinea pigs were observed in cages before experimental procedures were carried out.

\subsection{Animal Groupings}

The guinea pigs were put into five groups of 6 animals each. Two ovalbumin-sensitized groups receiving the Kalanchoe integra in high (HDK $=900 \mathrm{mg} / \mathrm{kg}$ ) and low (LDK = $300 \mathrm{mg} / \mathrm{kg}$ ) doses respectively, ovalbumin-sensitized control group received prednisolone (PRED = $2.5 \mathrm{mg} / \mathrm{kg}$ ), OA-sensitized control group (SC), Non-sensitized control (NORM or intact animals). All experimental procedures conformed to the OECD guidelines [27] [28] and the study protocol approved by the Scientific and Technical Committee (STC) and the Noguchi Memorial Institute for Medical Research Institutional Animal Care and Use Committee (NIACUC), College of Health Sciences, University of Ghana.

\subsection{Sensitization of Experimental Animals}

Ovalbumin and Aluminum hydroxide were obtained from the Biochemistry department, University of Ghana and used to induce the allergic asthma and boost the allergy respectively according to Awortwe et al. (2011) [29] with slight modifications.

All animal groups (except the non-sensitized negative controls) were sensitized with $10 \mathrm{mg}$ of ovalbumin and $30 \mathrm{mg}$ aluminum hydroxide intraperitoneally and subcutaneously at day zero.

\subsection{Immune Boosting Procedure}

$0.1 \mathrm{ml}$ of $0.9 \%$ saline containing only $15 \mathrm{mg}$ ovalbumin without adjuvant was administered to the sensitized guinea pigs by intraperitoneal route on day 14. The guinea pigs were observed for a period of one week after immune boosting. The diameter of the wheal for each guinea pig was monitored, as well as breathing patterns, eyes, motor activity and sensitivity to touch, for a period of one week till day 21.

\subsection{Ovalbumin Challenge, Drug Treatment and Skin Prick Test}

On the $25^{\text {th }}$ day through to $56^{\text {th }}$ day, sensitized guinea pigs were challenged with $2 \%$ aerosolized OA (0.2 g OA dissolved in $10 \mathrm{ml}$ saline) for $10 \mathrm{~min}$ after 1 hour treatment with High dose Kalanchoe (HDK), Low dose Kalanchoe (LDK) and Prednisolone, PRED (2.5 mg/kg) respectively. OA-sensitized controls were challenged with $0.1 \mathrm{ml}$ of $0.9 \%$ saline for the same duration. The challenge was conducted in Perspex chamber (dimensions $=20$ $\times 30 \mathrm{~cm}$ ) connected to jet nebulizer.

Skin prick test was used as an indirect measurement of IgE levels in the sensitized guinea pigs [29] [30]. The skin prick test was performed on day 56 by injecting 1\% ovalbumin intradermally on the back of each guinea pig after the fur was shaken (Figure 1).

\subsection{Haematological Studies}

Guinea pigs were anesthetized with $50 \mathrm{mg} / \mathrm{kg}$ sodium phenobarbitone. Two millilitres (2 ml) of blood was drawn by cardiac puncture and transferred into EDTA test tube. An automated haematology analyzer (KX-2IN, Sysmex Corporation, Japan) was used to estimate the counts of neutrophils, lymphocytes, eosinophils and total leukocytes in each blood sample. 


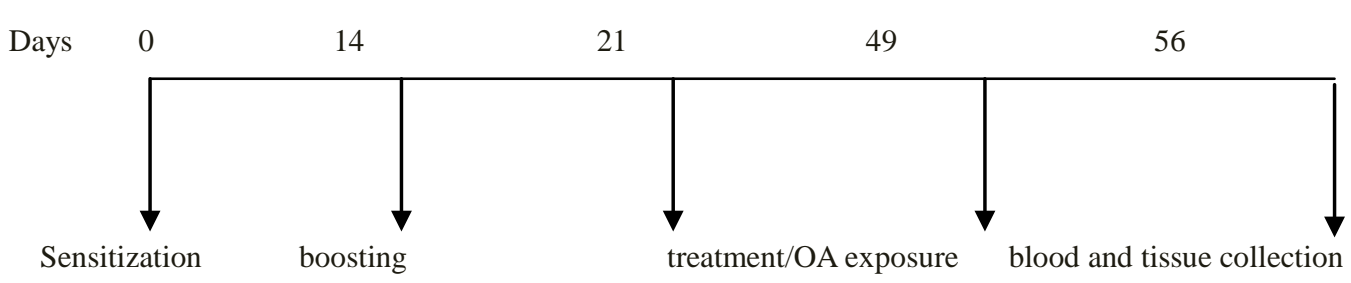

Figure 1. Schematic diagram of the experimental protocol indicating the events and durations.

\subsection{Histological Studies}

On the $56^{\text {th }}$ day, the guinea pigs were euthanized and blood taken by cardiac puncture. The lungs were swiftly excised from the thoracic cavity and washed immediately with $0.9 \%$ saline (four times). The tissues were fixed with $10 \%$ neutral buffered formaldehyde $(\mathrm{pH}=7.4)$, embedded in paraffin wax $\left(56^{\circ} \mathrm{C}\right.$ to $\left.60^{\circ} \mathrm{C}\right)$ and sectioned at $4 \mu \mathrm{m}$ for histopathological examination. The sectioned tissues were stained with hematoxylin and eosin (H\&E). Lung sections were evaluated microscopically using Olympus BX 51TF (Olympus Corporation, Tokyo, Japan) light microscope connected to a digital camera for morphology in the bronchioles. Images of selected sections were captured at $20 \times$ magnification.

For goblet cell identification, the periodic acid stain (PAS) stain was used while the PAS + AB (periodic acid Schiff + alcian blue) were used to differentiate between acid mucins and neutral mucins.

\subsection{Statistical Analysis}

Statistical analysis was done using Graphpad Prism 5. Means \pm SEM were determined for quantitative variables. In all cases values are expressed as mean \pm SEM. Statistics were performed using analysis of variance (ANOVA) was used to determine statistical significance invariables among the groups at p-values $\leq 0.05$ with subsequent Bonferroni post hoc test. p-values of less than 0.05 were considered significant.

\section{Results}

\subsection{Haematological Studies}

The counts of lymphocytes in the groups PRED, HDK, LDK, were $1300 \pm 30 \mu \mathrm{L}, 5100 \pm 24 \mu \mathrm{L}, 6000 \pm 45 \mu \mathrm{L}$. One way ANOVA showed a significant difference $(\mathrm{p}<0.001)$ in the lymphocyte counts of the five groups of animals. The counts of neutrophils in the groups PRED, HDK, LDK, were $2700 \pm 63 \mu \mathrm{L}, 2700 \pm 67 \mu \mathrm{L}, 2900 \pm$ $33 \mu \mathrm{L}$. One-way ANOVA show significant differences in the neutrophil count for the five groups $(p=0.0060)$. Benferroni's multiple comparison showed no significant difference between comparison between PRED and other groups ( $p>0.05$ ). The counts of eosinophils in the groups PRED, HDK, LDK were $248 \pm 22.7 \mu \mathrm{L}, 325 \pm$ $17 \mu \mathrm{L}, 400 \pm 25 \mu \mathrm{L}$. One-way ANOVA showed no significant differences between the groups $(\mathrm{p}=0.0149)$ as shown in Figure 2.

\subsection{Histological Studies}

The figures below show the lung tissues from the groups ovalbumin sensitized controls (SC) (Figure 3), 900 $\mathrm{mg} / \mathrm{kg}$ HDK (Figure 4), $2.5 \mathrm{mg} / \mathrm{kg}$ PRED (Figure 5) and normal (non-sensitized) guinea pigs (Figure 6) showing a description of the salient pathological features relevant to this study.

\subsection{Key}

Alveolus (a), Bronchiole (b), Blood Vessel (v), Peribronchial edema (e), Leukocystis Alveolitis (la), Pneumocystis (p), Perivascular edema (pe), Goblet cells (g), Smooth muscle (s), Emphysema (em), Bronchial Lumen (lu).

\subsubsection{Bronchial Smooth Muscle}

Guinea pigs administered with prednisolone exhibited bronchial smooth muscle thickness with an average of 1.9 \pm 0.994429 . Similar observations were found in High Dose Kalanchoe with an average of $1.7 \pm 0.875595$. The 


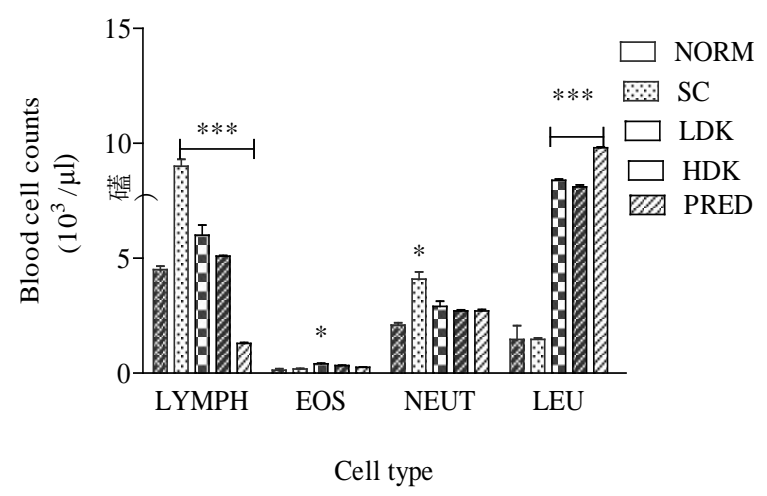

Figure 2. Changes in immune parameters during high dose (900 mg/kg) and low dose (300 mg/kg) Kalanchoe integra administration. Values are expressed as mean \pm SEM, $n=6$. The difference among means has been analyzed by ANOVA followed by bonferroni's multiple comparison. Values of $\mathrm{p}$ $<0.05$ were considered as statistically significant. ${ }^{*} \mathrm{p}<0.05$, ${ }^{* *} \mathrm{p}<0.01$ and ${ }^{* * *} \mathrm{p}<0.001$ when compared with $k$. integra.

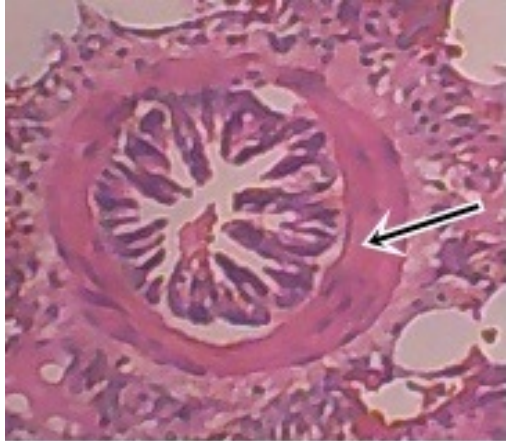

(a)

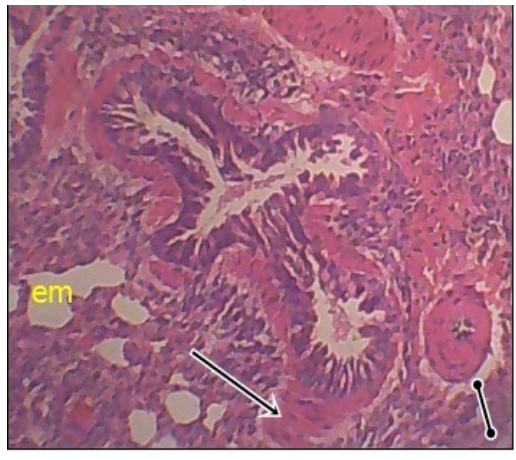

(d)

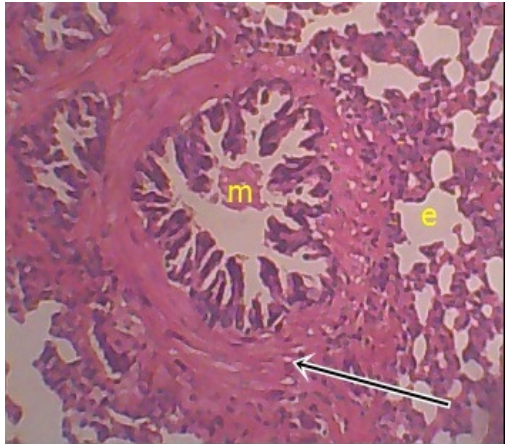

(b)

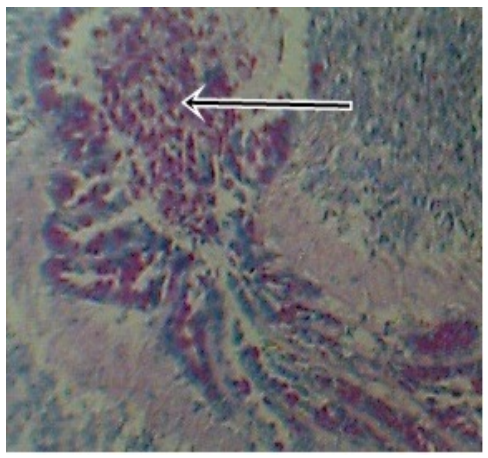

(e)

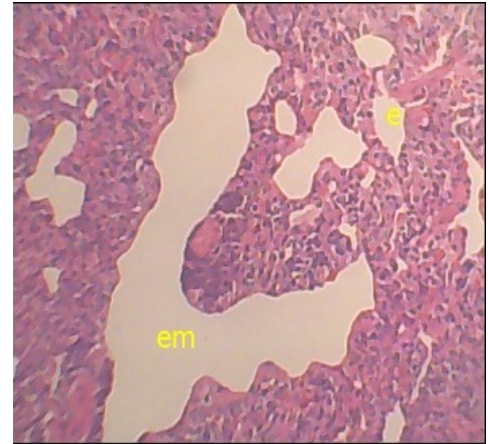

(c)

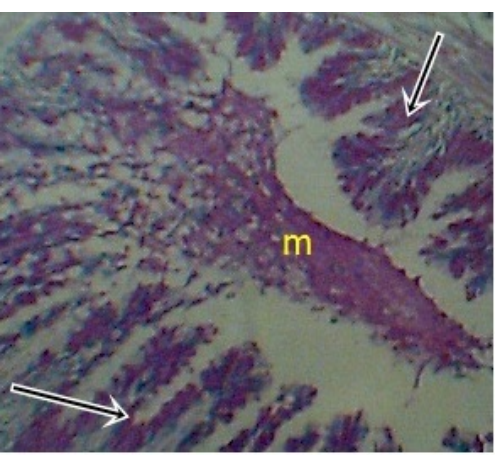

(f)

Figure 3. Photomicrographs of SC (a) increased smooth muscle thickness (b) significant increase in bronchial smooth muscle and presence of bronchial edema [e] and mucus $(\mathrm{m})(\mathrm{c})$ presence of emphysema and bronchial edema (Em and E) respectively (d) presence of perivascular edema and emphysema (em). (e) increased goblet cell accumulation (f) increased goblet cell accumulation and mucus (M). Magnification $\times 20$.

rest in the respective groups exhibited slightly reduced bronchial smooth muscle with an average of $2.2 \pm$ 0.632456 and $2.4 \pm 0.516398$.

\subsubsection{Goblet Cell Accumulation Evaluation}

Guinea pigs in the Kalanchoe treated group exhibited reduced goblet cell accumulation in the bronchioles com- 


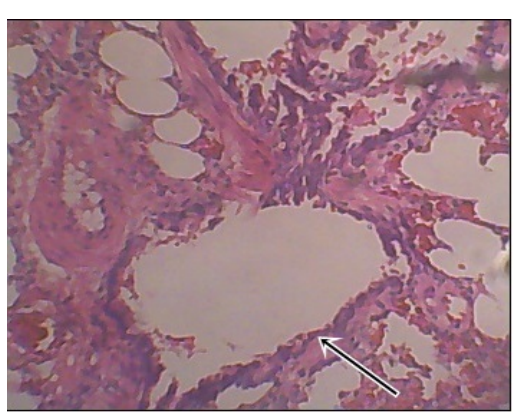

(a)

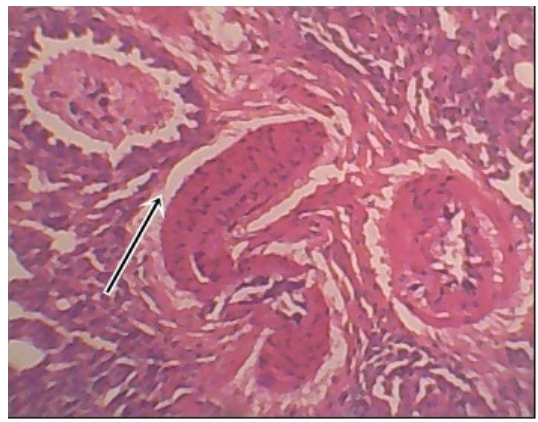

(d)

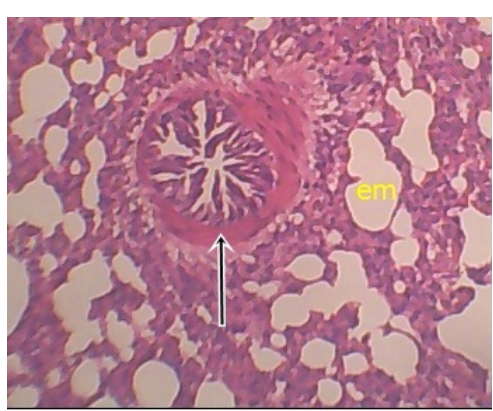

(b)

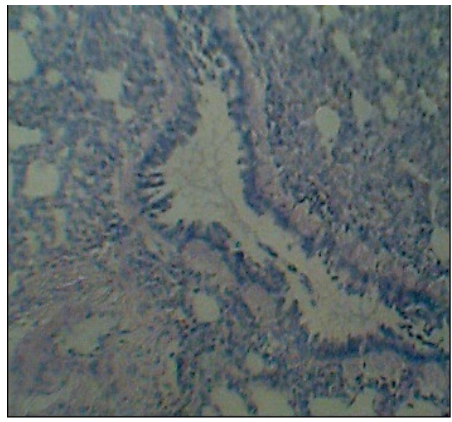

(e)

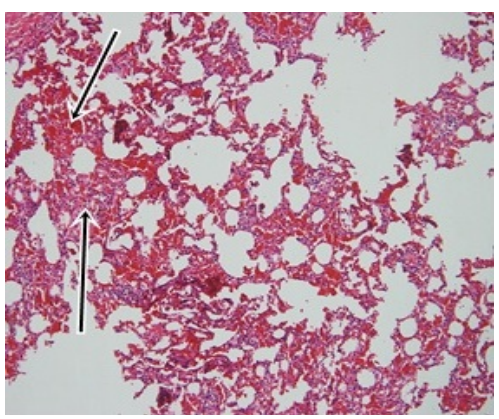

(c)

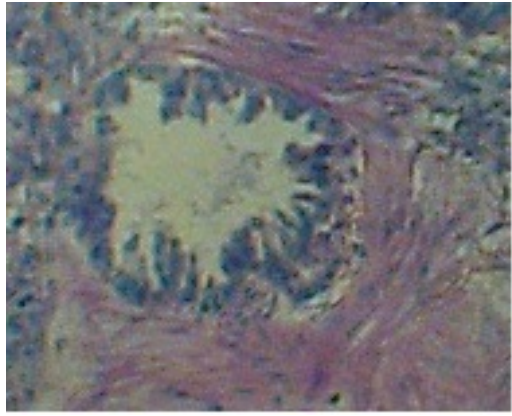

(f)

Figure 4. Photomicrographs of HDK $(900 \mathrm{mg} / \mathrm{kg}$ ) treated guinea pigs (a) drastically reduced smooth muscle thickness (b) reduced bronchial smooth muscle and presence of emphysema (em) (c) congestion in the alveolar blood vessel (d) perivascular edema. (e) and (f) very mild goblet cell accumulation. Magnification $\times 20$.



(a)



(d)

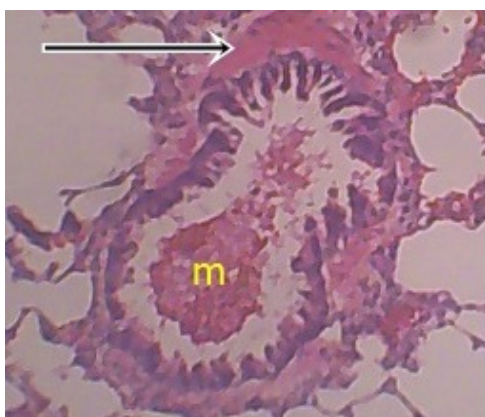

(b)

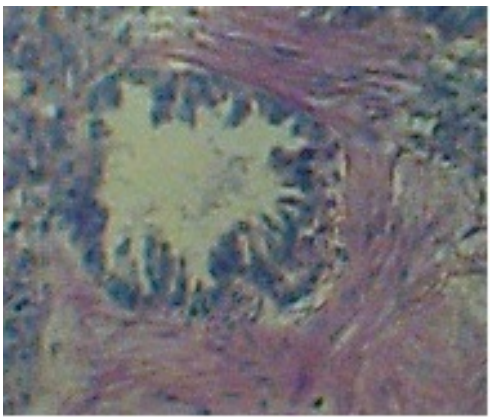

(e)

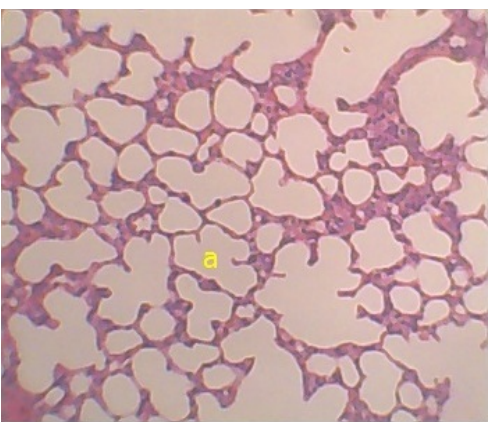

(c)

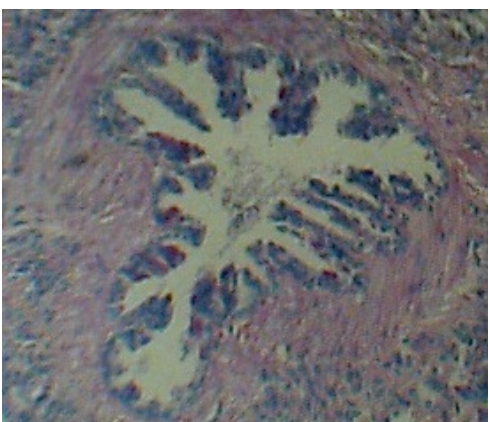

(f)

Figure 5. Photomicrographs of prednisolone $(2.5 \mathrm{mg} / \mathrm{kg}$ ) treated animals (a) reduced smooth muscle thickness, demonstrates the wide lumen of the bronchiole (Lu) (b) reduced bronchial smooth muscle, presence of mucus (m) (e) and(c) alveoli architecture is maintained (A) (d) presence of pneumocystis and the presence of perivascular edema. (f) no goblet cell accumulation. Magnification $\times 20$. 


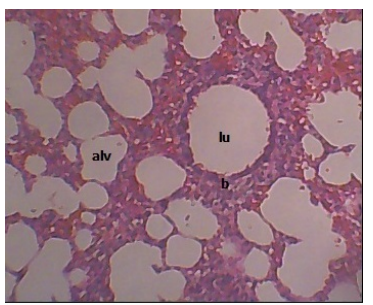

(a)

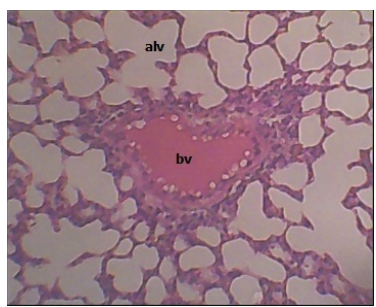

(b)

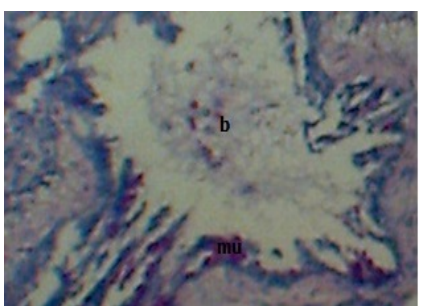

(c)



(d)

Figure 6. Photomicrographs of normal unsensitized guinea-pigs demonstrates the wide lumen of the bronchiole (Lu), alveoli architecture is maintained (alv) and no goblet cell accumulation. KEY: alv—alveolus; mu—mucin; b-bronchus; bvblood vessel; lu-lumen. Magnification $\times 20$.

pared to the controls.

\subsubsection{Co-Morbidities}

Hypersensitivity Pneumocystis was exhibited by all animals in all the groups with the exception of those administered with prednisolone. Three out of the six animals in the prednisolone group exhibited or maintained an appreciable normality in their alveoli architecture.

Emphysema was exhibited by all animals in all the groups with the exception of those administered with prednisolone.

\subsubsection{Bronchoconstriction}

Increased bronchial smooth muscle thickness and goblet cell accumulation usually indicates bronchoconstriction.

\section{Discussion}

In this study, the antiasthmatic potential of the nutraceutical KILE has been investigated. Pathophysiological parameters of bronchial asthma investigated include bronchial folds, bronchial wall thickness, alveoli, alveolar sacs, alveolar ducts and blood vessel walls. The immune parameters were also investigated.

Ovalbumin sensitized guinea pigs were preferred as experimental models for this study because they readily show airway hyper-reactivity and eosinophilia [29] [31] [32]. Ovalbumin-sensitized guinea pigs were challenged by inhalation of aerosolized ovalbumin antigen since asthmatic human subjects also experience airway hyperreactivity through similar route of antigen challenge [33] [34]. The inhalation of ovalbumin aerosols increased bronchial responsiveness: bronchoconstriction, hypertrophy of airway smooth muscle, infiltration of eosinophils and basophils, emphysema, peribronchial and perivascular oedema in the lungs of ovalbumin sensitized control guinea pigs compared to non-sensitized controls (Figure 3, Figure 6). These histological lesions observed in the lungs of ovalbumin sensitized guinea pigs are consistent with other findings [29] when a similar protocol was used to assess the anti-asthmatic actions of Taraxacum officinalis. It has been recognised for many years that patients who die from acute asthma attacks have grossly inflamed airways [35] [36]. Lymphocytes count during the experiment showed a significant difference $(\mathrm{p}<0.0001)$ between lymphocytes counts of KILE administered guinea pigs as compared to the negative controls (Figure 2). Also, the lymphocyte count for prednisolone treated group of guinea pigs was averagely 1300 counts/ $\mu \mathrm{L}$ (Figure 2) demonstrating the immunosuppressive effects of prednisolone as a corticosteroid. Other studies conducted [37] [38] portrayed a similar pattern.

Apart from the fact that phagocytes are among the many inflammatory cells and mediators released during severe infections or antigenic exposure in the lungs, neutrophils are also implicated in exacerbations of acute bronchial asthma [38]-[40]. Neutrophils count during the experiment indicated only a significant difference between High dose KILE group 2500 counts/ $\mu \mathrm{L}$ (Figure 2) and the prednisolone treated groups $(\mathrm{p}<0.0001)$. The ability of KILE to reduce both neutrophils and lymphocyte counts indicates its possible immunosuppressive effects and anti-asthmatic properties. Similar effects have been observed using extracts of Taraxacum officinalis [29]. However, recent observation that neutrophils undergo apoptosis rather than necrosis in the airways and alveoli is essential to defining pulmonary inflammation and repair [41]-[43].

KILE's significant reduction in the eosinophil and lymphocytes counts might have contributed to maintaining 
alveoli architecture compared to the sensitized negative control. A similar observation was made in the prednisolone treated animal groups and these are confirmed by other studies involving antiasthmatic agents [44]-[46].

Degranulation of eosinophils after infiltration into the lungs is a key player in the pathogenesis of asthma [47] [48]. Eosinophil activation produces a host of cationic proteins such as Major Basic Protein (MBP), Eosinophil Peroxidase (EPO) and eosinophil derived neurotoxin (EDN). Evidence from several studies has shown that these proteins are capable of damaging structures in the lung tissue while infiltrations of neutrophils in the lungs are increasingly being associated with exacerbations of acute asthma [47] [48]. KILE administration reduced these parameters as compared to the controls

Evaluating the ability of KILE to restore the already compromised bronchial airway patency as observed in the sensitized guinea pigs [negative control], the extent of bronchial smooth muscle hypertrophy or hyperplasia and goblet cell accumulation were monitored. Goblet cells are responsible for the production of mucin which later forms mucus in water. The higher the number of cells the more resulting mucus will be reduced which reduces the lumen of the bronchiole [51]-[53]. Goblet cells producing mucus on the other hand will stop the production of excess mucus once the exposure to the allergen is stopped much less when the cells die and the production of the mucus is reduced [52] [54]. Both smooth muscle thickness and number of goblet cells correlate with the degree of airway obstruction in this disease, supporting a role for airway remodelling and mucus hypersecretion in the development of airflow limitation in asthmatics [17] [19] [20]. Besides, thickening of the airway wall, hypertrophy of mucous glands, increased smooth muscle mass and hyperplasia of goblet cells have been reported in patients with COPD [55]-[57].

KILE exhibited reasonable reduction in goblet cell accumulation (Figure 4), a situation considered non-critical especially when other pathological parameters remain normal or reduced. Prednisolone on the other hand shows slight effect against HP since it was able to maintain normality to aspects of the guinea pig alveoli architecture (Figure 5). Emphysema, which has also been found in ovalbumin sensitized guinea pigs (Figure 3) was also reduced by KILE (Figure 4).

Bronchial smooth muscle thickness is a parameter of primary importance due to its irreversible nature [12]. Both LD and HD KILE appreciably reduced bronchial smooth muscle hypertrophy, hyperplasia and subepithelial fibrosis which are very characteristic of bronchial asthma [12] [18] [35]. This corresponded to a reduced bronchial smooth muscle thickness (Figure 4) which in this case could be considered non critical because other parameters leading to bronchoconstriction remain reduced or normal. Prednisolone however had a more pronounced effect in reducing smooth muscle hypertrophy or hyperplasia and subepithelial fibrosis (Figure 5).

One peculiar observation in this study is the presence of both immediate-phase and late-phase asthmatic responses in the photomicrographs of the ovalbumin sensitized guinea pigs. Immediate-phase asthmatic response was evidenced by the presence of bronchoconstriction (Figure 3) whilst recruitment of eosinophils and basophils, hypertrophy of the trachealis muscle, emphysema, peribronchial oedema and perivascular oedema (Figure 3) were signs for late-phase asthmatic response [16] [58]-[60]. KILE reduced these parameters as compared to the negative controls. It would be desirable to elucidate the mechanism by which KILE exhibits this effect and to isolate and characterize the compounds responsible.

The above observations contribute to the pharmacological validation that KILE when taken orally for long periods could be beneficial in the management of bronchial asthma. This could partly be explained by kalanchoe's antioxidant properties as well as the presence of quercetin in KILE because previous studies have implicated quercitrin as having an anti-inflammatory and bronchodilatatory effect therefore it is possible that this same flavonoid in $K$. integra together with phenolic and tannin compounds may also be responsible its antiasthmatic activity [24] [49] [50]. The active components of KILE are recommended to be further investigated.

\section{Conclusion}

Kalanchoe integra leaf extract reduces bronchoconstriction, immune responses, goblet cell accumulation and smooth muscle thickness comparable to prednisolone. The above effects prove that KILE is a promising nutraceutical having anti-asthmatic potential.

\section{Acknowledgements}

The authors acknowledge the "manuscript writing” financial support of "Building Stronger Universities Initiative Platform on Human Health” (BSU-PHH)-Department of Pharmacology and Toxicology, University of 
Ghana School of Pharmacy, College of Health Sciences.

\section{Conflict of Interest}

The authors declare there is no conflict of interest.

\section{References}

[1] Pandey, M., Debnath, M., Gupta, S. and Chikara, S.K. (2011) Phytomedicine: An Ancient Approach Turning into Future Potential Source of Therapeutics. Journal of Pharmacology and Phytotherapy, 3, 27-37.

[2] Dymock, W., Warden, C.J.H. and Hooper, D. (1890) Pharmacographica Indica. Trubner \& Co. London, Educational Society's Press, Calcutta, 1, 590.

[3] Dokosi, O.B. (1998) Herbs of Ghana. 32-33.

[4] Biswas, S.K., Chowdhury, A., Das, J., Hosen, S.Z., Uddin, R. and Rahaman, M.S. (2011) Literature Review on Pharmacological Potentials of Kalanchoe pinnata (Crassulaceae). African Journal Pharmarcy and Pharmacology, 5, 12581262. http://dx.doi.org/10.5897/AJPP11.273

[5] Ghasi, S., Egwuib, C., Achukwu, P. and Onyeanusi, J. (2011) Assessment of the Medical Benefit in the Folkloric Use of Bryophyllum Pinnatum Leaf among the Igbos of Nigeria for the Treatment of Hypertension. African Journal Pharmarcy and Pharmacology, 5, 83-92. http://dx.doi.org/10.5897/AJPP10.309

[6] Cruz, E., Da-silva, S., Muzitano, M., Silva, P., Costa, S. and Rossi-Bergmann, B. (2008) Immunomodulatory Pretreatment with Kalanchoe pinnata Extract and Its Quercitrin Flavonoid Effectively Protects Mice against Fatal Anaphylactic Shock. International Immunopharmacology, 8, 1616-1621. http://dx.doi.org/10.1016/j.intimp.2008.07.006

[7] Harlalka, G.V., Patil, C.R. and Patil, M.R. (2007) Protective Effect of Kalanchoe pinnata pers. (Crassulaceae) on Gentamicin-Induced Nephrotoxicity in Rats. Indian Journal of Pharmacology, 39, 201. http://dx.doi.org/10.4103/0253-7613.36540

[8] Ojewole, J.A. (2005) Antinociceptive, Anti-Inflammatory and Antidiabetic Effects of Bryophyllum pinnatum (Crassulaceae) Leaf Aqueous Extract. Journal of Ethnopharmacology, 99, 13-19. http://dx.doi.org/10.1016/j.jep.2005.01.025

[9] Cruz, E., Reuter, S., Martin, H., Dehzad, N., Muzitano, M., Costa, S., Rossi-Bergmann, B., Buhl, R., Stassen, M. and Taube, C. (2012) Kalanchoe pinnata Inhibits Mast Cell Activation and Prevents Allergic Airway Disease. Phytomedicine, 19, 115-121. http://dx.doi.org/10.1016/j.phymed.2011.06.030

[10] Okwu D.E. and Nnamdi F.U. (2011) Two Novel Flavonoids from Bryophyllum pinnatum and Their Antimicrobial Activity. Pharmacy and Respiratory Journal, 3, 1-10.

[11] Theide, J. and Eggli, U. (2007) Crassulaceae. Flowering Plants. Eudicots, Springer.

[12] Barnes, P.J. (1996) Pathophysiology of Asthma. British Journal of Clinical Pharmacology, 42, 3-10. http://dx.doi.org/10.1046/j.1365-2125.1996.03721.x

[13] Broide, D.H., Gleich, G.J., Cuomo, A.J., Coburn, D.A., Federman, E.C., Schwartz, L.B. and Wasserman, S.I. (1991) Evidence of ongoing Mast Cell and Eosinophil Degranulation in Symptomatic Asthma Airway. Journal of Allergy and Clinical Immunology, 88, 637-648. http://dx.doi.org/10.1016/0091-6749(91)90158-K

[14] Larzarus, S.S., Boushey, H., Fahy, J., Chinchili, V., Lemanske, R., Sorkness, C., Kraft, M., Fish, J., Peters, S. and Craig, T. (2001) Long-Acting Beta2-Agonist Monotherapy vs Continued Therapy with Inhaled Corticosteroids in Patients with Persistent Asthma: A Randomized Controlled Trial. The Journal of the American Medicine Association, 285, 2583-2593. http://dx.doi.org/10.1001/jama.285.20.2583

[15] Minic, P. and Sovtic, A. (2008) The Use of Corticosteroids in Pediatric Respiratory Disease. Arhiv za Farmaciju, 58, 172-184.

[16] Johansson, M.W., Han, S.T., Gunderson, K.A., Busse, W.W., Jarjour, N.N. and Mosher, D.F. (2012) Platelet Activation, P-Selectin and Eosinophil $\beta 1$-Integrin Activation in Asthma. American Journal of Respiratory Cell and Molecular Biology, 185, 498-507.

[17] Bloemen, K., Ver straelen, S., Van Den Heuvel, R., Witters, H., Nelissen, I. and Schoeters, G. (2007) The Allergic Cascade: Review of the Most Important Molecules in the Asthmatic Lung. Immunology Letters, 113, 6-18. http://dx.doi.org/10.1016/j.imlet.2007.07.010

[18] Fahy, J.V., Corry, D.B. and Boushey, H.A. (2000) Airway Inflammation and Remodeling in Asthma. Current Opinion in Pulmonary Medicine, 6, 15-20. http://dx.doi.org/10.1097/00063198-200001000-00004

[19] Durham, S.R., Till, S.J. and Corrigan, C.J. (2000) T Lymphocytes in Asthma: Bronchial versus Peripheral Responses. 
Journal of Allergy and Clinical Immunology, 106, S221-S226. http://dx.doi.org/10.1067/mai.2000.110154

[20] Di-Stefano, A., Diane, M.C., Schick, C.M. and McKelvy, J.F. (2001) Decreased T Lymphocyte Infiltration in Bronchial Biopsies of Subjects with Severe Chronic Obstructive Pulmonary Disease. Clinical \& Experimental Allergy, 31, 893-902. http://dx.doi.org/10.1046/j.1365-2222.2001.01098.x

[21] Park, H.J., Lee, C.M., Jung, I.D., Lee, J.S., Jeong, Y.I., Chang, J.H., Chun, S.H., Kim, M.J., Choi, I.W., Ahn, S.C., Shin, Y.K., Yeom, S.R. and Park, Y.M. (2009) Quercetin Regulates Th1/Th2 Balance in a Murine Model of Asthma. International Immunopharmacology, 9, 261-267. http://dx.doi.org/10.1016/j.intimp.2008.10.021

[22] Joskova, M., Franova, S. and Sadlonova, V. (2011) Acute Bronchodilator Effect of Quercetin in Experimental Allergic Asthma. Bratislavské Lekárske Listy, 112, 9-12.

[23] Fortunato, L.R., de Freitas Alves, C., Teixeira, M.M. and Rogerio, A.P. (2012) Quercetin: A Flavonoid with the Potential to Treat Asthma. Brazilian Journal of Pharmaceutical Sciences, 48, 4. http://dx.doi.org/10.1590/S1984-82502012000400002

[24] Asiedu-Gyekye, I.J., Awortwe, C., Antwi, D., et al. (2013) Comparative Study of Two kalanchoe Species: Total Flavonoid, Phenolic Contents and Antioxidant Properties. African Journal of Pure and Applied Chemistry, 6, 65-73.

[25] Pattewar, S.V. (2012) Kalanchoe pinnata: Phytochemical and Pharmacological Profile. International Journal of Phytopharmarcy, 2, 1-8.

[26] Asiedu-Gyekye, I.J., Awortwe, C., Tagoe, B.N.A., Antwi, D.A., Adjei, S., Edusei, I.D., N’guessan, B.B., Amoateng, P. and Nkansah, E. (2014) Preliminary Investigation into the Antiasthmatic Potential of Kalanchoe Integra Leaf Extract Using a Model of Allergic Airway Inflammation. European Journal of Medicinal Plants, 4, 542-562.

[27] Organization for Economic Cooperation and Development (OECD) (2001) Guidelines. Guidelines for Testing of Chemicals.

[28] WHO (2000) General Guidelines for Methodologies on Research and Evaluation of Traditional Medicine. Geneva, 80.

[29] Awortwe, C., Sackeyfio, A., Osei-safo, D., Bugyei, K. and Asiedu-Gyekye, I. (2011) Dual Effect of Taraxacum Officinale Leaves Anticholinergic and Inhibitory Effect on Inflammatory Cells in Ovalbumin-Sensitized Guinea-Pigs. African Journal of Pharmacy and Pharmacology, 5, 2613-2619. http://dx.doi.org/10.5897/AJPP11.616

[30] Droste, J.H., Kerhof, M., Monchy, J.G. de, Schouten, J.P. and Rijcken, B. (1996) Association of Skin Test Reactivity, Specific IgE, Total IgE, and Eosinophils with Nasal Symptoms in a Community-Based Population Study. Journal Allergy Clinical Immunology, 97, 922-932. http://dx.doi.org/10.1016/S0091-6749(96)80066-2

[31] Koh, H.S., Lee, K.S., Han, D.H., Rha, Y.H. and Choi, S.H. (2013) Relationship between Serum Total IgE, Specific IgE, and Peripheral Blood Eosinophil Count According to Specific Allergic Diseases. Allergy Asthma \& Respiratory Disease, 1, 123-128. http://dx.doi.org/10.4168/aard.2013.1.2.123

[32] Krieger, S.M., Poole, A., Wienskinki, C.M. and Woolshier, M.R. (2008) Respiratory Sensitization and Allergy: Current Research Approaches and Needs. Toxicology \& Applied Pharmacology, 226, 1-13. http://dx.doi.org/10.1016/j.taap.2007.10.008

[33] Parmar, S.K., Gangwal, A.P., Prajapati, T.R., Pandya, K.B., Ranpariya, V.L. and Sheth, N.R. (2010) Evaluation of Antiasthmatic Activity of a Polyherbal Formulation Containing Four Plant Extracts. Journal of Current Pharmaceutical Respiration, 2, 40-44.

[34] Pandit, P., Singh, A., Bafna, A.R., Kadam, P.V. and Patil, M.J. (2008) Evaluation of Antiasthmatic Activity of Curculigo orchioides Gaertn. rhizomes. Indian Journal of Pharmaceutical Science, 70, 440. http://dx.doi.org/10.4103/0250-474X.44590

[35] Bousquet, J., Jeffery, P.K., Busse, W.W., Johnson, M. and Vignola, A.M. (2000) Asthma from Bronchoconstriction to Airways Inflammation and Remodeling. American Journal of Respiration and critical care Medicine, 161, 1720-1745. http://dx.doi.org/10.1164/ajrccm.161.5.9903102

[36] Minai-Fleminger, Y. and Levi-Schaffer, F. (2009) Mast Cells and Eosinophils: The Two Key Effector Cells in Allergic Inflammation. Inflammation Research, 58, 631-638. http://dx.doi.org/10.1007/s00011-009-0042-6

[37] Schall, T.J. and Bacon, K.B. (994) Chemokines, Leukocyte Trafficking, and Inflammation. Current Opinion in Immunology, 6, 865-873. http://dx.doi.org/10.1016/0952-7915(94)90006-X

[38] Gundel, R.H., Wegner, C.D. and Letts, L.G. (1992) The Onset and Recovery from Airway Hyperresponsiveness: Relationship with Inflammatory Cell Infiltrates and Release of Cytotoxic Granule Proteins. Clinical \& Experimental Allergy, 22, 303-308. http://dx.doi.org/10.1111/j.1365-2222.1992.tb03087.x

[39] Montefort, S., Herbert, C.A., Robinson, C. and Holgate, S.T. (1992) The Bronchial Epithelium as a Target for Inflammatory Attack in Asthma. Clinical \& Experimental Allergy, 22, 511-520. http://dx.doi.org/10.1111/j.1365-2222.1992.tb00159.x

[40] Merwat, S.N. and Spechler, S.J. (2009) Might the Use of Acid-Suppressive Medications Predispose to the Develop- 
ment of Eosinophilic Esophagitis? A Matter of Opinion. The American Journal of Gastroenterology, 104, 1897-1902. http://dx.doi.org/10.1038/ajg.2009.87

[41] Robinson, D.S., Hamid, Q., Ying, S., Tsicopoulos, A., Barkans, J., Bentley, A.M., Corrigan, C., Durham, S.R. and Kay, A.B. (1992) Predominant TH2-Like Bronchoalveolar T-Lymphocyte Population in Atopic Asthma. New England Journal of Medicine, 326, 298-304. http://dx.doi.org/10.1056/NEJM199201303260504

[42] Rakh, M.S., Khedkar, A.N., Aghav, N.N. and Chaudhari, S.R. (2012) Antiallergic and Analgesic Activity of Momordica dioica Roxb. Willd Fruit Seed. Asian Pacific Journal of Tropical Biomedicine, 2, S192-S196. http://dx.doi.org/10.1016/S2221-1691(12)60157-9

[43] Gomes, D., Muzitano, M., Costa, S. and Rossi-Bergmann, B. (2010) Effectiveness of the Immunomodulatory Extract of Kalanchoe pinnata against Murine Visceral Leishmaniasis. Parasitology, 137, 613-618. http://dx.doi.org/10.1017/S0031182009991405

[44] Bousquet, J., Chanez, P., Lacoste, J.Y., Barnéon, G., Ghavanian, N., Enander, I., Venge, P. and Ahlstedt, S. (1990) Eosinophilic Inflammation in Asthma. New England Journal of Medicine, 323, 1033-1039. http://dx.doi.org/10.1056/NEJM199010113231505

[45] Desai, S.N., Van, G., Robson, J., Letts, L.G., Gundel, R.H., Gleich, G.J., Piper, P.J. and Noonan, T.C. (1993) Human Eosinophil Major Basic Protein Augments Bronchoconstriction Induced by Intravenous Agonists in Guinea Pigs. Agents and Actions, 39, C132-C135. http://dx.doi.org/10.1007/BF01972744

[46] Gundel, R.H., Letts, L.G. and Gleich, G.J. (1991) Human Eosinophil Major Basic Protein Induces Airway Constriction and Airway Hyperresponsiveness in Primates. Journal of Clinical Investigation, 87, 1470-1473. http://dx.doi.org/10.1172/JCI115155

[47] Durham, S.R., Loegering, D.A., Dunnette, S., Gleich, G.J. and Kay, A.B. (1989) Blood Eosinophils and EosinophilDerived Proteins in Allergic Asthma. Journal of Allergy and Clinical Immunology, 84, 931-936. http://dx.doi.org/10.1016/0091-6749(89)90391-6

[48] Mahajan, S.G. and Mehta, A.A. (2011) Suppression of Ovalbumin-Induced Th2-Driven Airway Inflammation by $\beta$-Sitosterol in a Guinea Pig Model of Asthma. European Journal of Pharmcology, 650, 458-464. http://dx.doi.org/10.1016/j.ejphar.2010.09.075

[49] Hamid, A.A., Aiyelaagbe, O.O., Usman, L.A., Ameen, O.M. and Lawal, A. (2010) Antioxidants: Its Medicinal and Pharmacological Applications. African Journal of Pure and Applied Chemistry, 4, 142-151.

[50] Bhatti, M., Kamboj, A., Saluja, A.K. and Jain, U.K. (2012) In Vitro Evaluation and Comparison of Antioxidant Activities of Various Extracts of Leaves and Stems of Kalanchoe pinnatum. International Journal of Green Pharmarcy, 6, 340-347. http://dx.doi.org/10.4103/0973-8258.108255

[51] Khakzad, M.R., Mirsadraee, M., Mohammadpour, A., Ghafarzadegan, K., Hadi, R., Saghari, M. and Meshkat, M. (2012) Effect of Verapamil on Bronchial Goblet Cells of Asthma: An Experimental Study on Sensitized Animals. Pulmonary Pharmacology \& Therapeutics, 25, 163-168. http://dx.doi.org/10.1016/j.pupt.2011.11.001

[52] Kondo, M., Nakata, J., Arai, N., Izumo, T., Tagaya, E., Takeyama, K., Tamaoki, J. and Nagai, A. (2012) Niflumic Acid Inhibits Goblet Cell Degranulation in a Guinea Pig Asthma Model. Allergology International, 61, 133-142. http://dx.doi.org/10.2332/allergolint.11-OA-0307

[53] Mushaben, E.M., Kramer, E.L., Brandt, E.B., Khurana Hershey, G.K. and Cras, T.D. (2011) Rapamycin Attenuates Airway Hyperreactivity, Goblet Cells, and IgE in Experimental Allergic Asthma. Journal of Immunology, 187, 57565763. http://dx.doi.org/10.4049/jimmunol.1102133

[54] Hays, S.R., Woodruff, P.G., Khashayar, R., Ferrando, R.E., Liu, J., Fung, P., Zhao, C.Q., Wong, H.H. and Fahy, J.V. (2001) Allergen Challenge Causes Inflammation but Not Goblet Cell Degranulation in Asthmatic Subjects. Journal of Allergy and Clinical Immunology, 108, 784-790. http://dx.doi.org/10.1067/mai.2001.119162

[55] Kanani, A., Schellenberg, R. and Warrington, R. (2011) Urticaria and Angioedema. Allergy, Asthma \& Clinical Immunology, 7, S9. http://dx.doi.org/10.1186/1710-1492-7-S1-S9

[56] Papiris, S.A., Manali, E.D., Kolileas, L., Traintafillido, C. and Tsangaris, I. (2009) Acute Severe Asthma: New Approaches to Assessment and Treatment. Drugs, 69, 2363-2391.

[57] Bochner, B.S. and Busse, W. (2005) Allergy and Asthma. Journal of Allergy and Clinical Immunology, 115, 953-959. http://dx.doi.org/10.1016/j.jaci.2005.02.032

[58] Bajoriūnienė, I., Malakauskas, K., Lavinskienė, S., Jeroch, J., Vitkauskienė, A. and Sakalauskas, R. (2012) Peripheral Blood Th17 Cells and Neutrophils in Dermatophagoides Pteronyssinus-Induced Early- and Late-Phase Asthmatic Response. Medicina, 48, 442-451.

[59] Pradalier, A. (1993) Late-Phase Reaction in Asthma: Basic Mechanisms. International Archives of Allergy and Immunology, 101, 322-325. http://dx.doi.org/10.1159/000236471

[60] Arvidsson, M.B., Löwhagen, O. and Rak, S. (2007) Early and Late Phase Asthmatic Response in Lower Airways of 
Cat-Allergic Asthmatic Patients-A Comparison between Experimental and Environmental Allergen Challenge. Allergy, 62, 488-494. http://dx.doi.org/10.1111/j.1398-9995.2007.01278.x

\section{Abbreviations}

KILE: Kalanchoe integra leaf extract;

SC: sensitized control;

LD: low dose;

HD: high dose;

LDK: low dose kalanchoe;

HDK: high dose kalanchoe;

PRED: prednisolone;

Alveolus (a);

Bronchiole (b);

Blood Vessel (v);

Peribronchial edema (e);

Leukocystis Alveolitis (la);

Pneumocystis (p);

Perivascular edema (pe);

Goblet cells (g),;

Smooth muscle (s);

Emphysema (em);

Bronchial Lumen (lu). 